\title{
Study on the Value of Carrying out Rhythmic Gymnastics Course in Higher Vocational Colleges
}

\author{
Lingling Deng \\ Wuhan International Trade University \\ Wuhan, China
}

\begin{abstract}
The level of social development is the level of displaying human talents in an all-round way. High-quality art appreciation classes have been opened up in higher vocational colleges against the high requirement of talents by the current society including rhythmic gymnastics course, which is an innovation and breakthrough move to adapt to the compound talents training mode needed by the society. Practice has proved that the overall quality of students has been greatly improved under the nurturing of this course, thus they are able to adapt to the needs of society for all levels of talents. Therefore, this paper explores the artistic value of rhythmic gymnastics course starting from the perspective of educational psychology, sports physiology and artistic esthetics, so as to establish the necessity of offering rhythmic gymnastics course in higher vocational colleges.
\end{abstract} value

Keywords-higher vocational college; rhythmic gymnastics;

\section{INTRODUCTION}

Higher vocational college education is an important part of higher education in our country. The essential task of it is to cultivate the applied specialized talents who have advanced technology and an all-round development in the aspects of moral, intellectual, physical and aesthetic as well as adapt to the urgent need for production, construction and management services. The flexibility and innovation of higher vocational college education determine the diversification and adaptability of its talent cultivation mode. It aims to cultivate applied talents, with a view to expand students' ability of technical application. At the same time, with respect to constructing curriculum and teaching content system, its own "application" features are also highlighted. With the guidance of this teaching philosophy, students can master the basic ability and basic skills for engaging in the practical work of this professional field based on mastering the necessary basic theoretical knowledge and professional knowledge, having good professional ethics and professional ethics. Graduates should have appropriate basic theoretical knowledge, strong technology application ability, wide knowledge and high quality.

High-quality art appreciation classes have been opened up in higher vocational colleges against the high requirement of talents by the current society, including rhythmic gymnastics course, which is an innovation and breakthrough move to adapt to the compound talents training mode needed by the society. Practice has proved that the overall quality of students has been greatly improved under the nurturing of this course, thus they are more able to adapt to the needs of society for all levels of talents.

\section{CHARACTERISTICS OF RHYTHMIC GYMNASTICS}

\section{A. Comprehensive Beauty}

Rhythmic gymnastics is a relatively new type of sport integrating dance, artistic gymnastics, technique, martial arts, acrobatics and drama as a whole. It is a rhythmical sport characterized by elegance with natural and rhythmic movements as basis. It is composed of jumping, dancing, swinging, balancing, elasticity, wave motion and some skill movements, showing the beauty of sports through changes of rhythm, strength, amplitude, speed and posture, as well as the beauty of modeling, rhythm, music and human body.

\section{B. Artistry}

Practicing rhythmic gymnastics accompanying by music will not only help learners to experience and feel various movement rhythms and style features, but also conducive to adjust the muscle contraction strength, cultivate the sense of rhythm and coordination. It helps to stimulate the desire and passion of the learner, encourage learners to do their best to complete the exercise plan, grasp the movement rhythm, and complete the movement accurately. Through the physical movement, strength, amplitude, speed and posture modeling changes, rhythmic gymnastics teaching enrich the learner's appeal, imagination and expression, improve the learner's music accomplishment, cultivate good temperament, enabling people to be more physically and mentally pleasant, to have more interest in it, so as to focus on it selflessly.

\section{Universality}

Rhythmic gymnastics is easy to learn as its movements are simple, exercise intensity is not high, and has no high requirements for physical quality, and most people can participate. The training content of rhythmic gymnastics can be selected according to learners' age, sex, interest and purpose. The number of learners is unlimited and they can do exercises indoors or outdoors, which is suitable for students' needs. 


\section{VALUE OF OPENING UP ARTISTIC PHYSICAL EDUCATION IN HigHER VOCATIONAL COLLEGES}

\section{A. Educational Value}

1) Improve the ability of self-awareness and selfmanagement: Students in the training and performance, in appreciation of other people's process, can carry out selfeducation, awareness of their own deficiencies, so as to constantly improve themselves, so that their own progress; the learners can cultivate themselves to arrange their own training contents, training plan, and training load scientifically and reasonably in the process of exercises, and improve the effectiveness of self-training in the course of constant selfcheck; if they apply this method to all the studies simultaneously, their learning efficiency will be improved greatly.

2) Improve students' consciousness and enthusiasm: Students shall connect the training purpose of rhythmic gymnastics with professional needs closely linked, and with the establishment of establishment of a correct outlook on life while do exercises. Only after students have a more profound understanding of the position of rhythmic gymnastics training in profession as well as in modern life and work, can they regard training as the conscious needs in learning and life, so as to stimulate the initiative and enthusiasm for training. Interest is the best teacher. One will not show great initiative to achieve physical and mental unity and to learn and do exercise consciously if he has no interest. Rhythmic gymnastics training process is a self-training, selfimprovement process. Teachers shall teach students to overcome their inertia and various difficulties. Through the training process, students gradually develop an attitude of conscious and positive learning, changing "want me to learn" to "I want to learn", thus they can attain the learning result with half effort.

3) Improve students' artistic accomplishment: The sports that create beauty can stimulate students' emotions, enabling students to be imaginative while they are personally involved in the process, to express the inner feelings in full, and to bring pleasure and aesthetic experience to their own body and mind; guide students to seek the beauty of nature as well as the beauty in real life, stimulate students to pursue higher and more beautiful realm; guide students to pursue the lofty ideals and sentiments, to improve their literary and artistic accomplishment, as well as their ability to express beauty.

4) Cultivate students' sense of collective honor: In training process of rhythmic gymnastics, there is a set of collective movements and exercises of queue changes, which require students to unite and work together to increase interpersonal contact, build up students' ability of communicating with each other, and improve students' interpersonal skills; at the same time, students' sense of loneliness can also be eliminated, enabling students to recognize the relationship between individuals and collective, and cultivate students with organized and disciplined concept of collectivism honor that advocates solidarity and mutual support.

5) Cultivating students' professional accomplishment: Rhythmic gymnastics training can rationalize students' impetuous mentality gradually, as well as develop their good thinking, learning, creation and adaptation ability; make students change to different degrees in terms of their physical, psychological, ideological and professional qualities, so that they are confidant and charming, and have good professional quality to be able to work in the society.

6) Beautify the society and understand the world: With the development of today 's society, there are much higher requirements for talents' comprehensive quality. Graduates graduating from higher vocational college shall adapt themselves to social needs, to obtain recognition from the fierce talent competition. They also need to have a well-built body shape and elegant temperament, as well as modern manners in addition to certain professional and technical knowledge and skills. The rhythmic gymnastics course can offer training against these targets and achieve good results. In the process of learning, students can learn more about colorful modern social life, and people's emotional changes in life, so as to understand the real life correctly and treat life with healthy attitude, to achieve self-realization with wellbuilt body, obtain certain social benefits to create a beautiful atmosphere for the society. Recognize life, understand the world and create a better future in the activities of beautyappreciation and beauty creation.

\section{B. Value of Sports}

1) Exercise students' body in an all-round way and enhance their physical fitness: Offering stimulation to various organs and systems with certain intensity and amount of exercise through comprehensive body exercises can make the body generate a series of adaptive response in the aspects such as physiological function. Meanwhile, it can develop the basic physical qualities such as strength, endurance, agility, and flexibility. Healthy and good physical fitness is the physical condition necessary for each student.

2) Shape body shape and elegant posture: Scientific training not only can change the primitive state of the body, but also can cultivate correct postures, such as sitting, standing and walking, as well as elegant temperament. Posture beauty, gesture beauty, and action beauty are particularly important for specific occupations. For example, aviation services, hotel service management and other professional. Body shape and gesture can be improved through the practice of rhythmic gymnastics, so that they can adapt to job requirements faster, to improve work efficiency, create a dynamic environment, thus to improve service quality .

\section{Physiological Value}

1) Improve the function of students' nervous system, and enhance learning efficiency: Nervous system is the center of human body's automatic control system, being responsible for 
maintaining the body's steady state. Rhythmic gymnastics training can improve the regulating function of nervous system, improve the ability of the nervous system to judge different changes in human activities, and make timely, accurate and rapid response, so that the nervous system can be exercised and strengthened.

On the other hand, when the human body is tired after a long time mental work, at this moment, short-time rhythmic gymnastics training can transfer the excitement center of cortex, so that the previous excited nerve cells can get a good rest, at the same time, the oxygen and nutrients are added. If the brain tissue oxygen and nutrients have been improved, then the brain tissue learning efficiency can be significantly improved.

2) Enhance the function of students' cardiovascular system, and improve their athletic ability: During the training, students' myocardium is often in a state of intense contraction, the muscle fibers gradually thicken, the atria and the ventricular wall thicken, the heart volume increases, the blood volume increases and the heart beat frequency decreases, which greatly reduces the work load of the heart. At the same time, exercise can make alveoli fully open, which is conducive to alveoli's growth and elasticity maintenance, which has increased lung capacity.

It also has a very significant role on the blood vessels. It can consume the excess fat around blood vessel wall, make blood vessel wall flexible, increase caliber, increase blood flow, thus to enable the heart to get adequate oxygen and nutrients, so as to improve students' athletic ability.

3) Correct students' skeletal form, improve muscle lines, and enhance students' self-confidence: Bone growth and development are closely related to human hormones. The normal activities of hormones and normal development of bones can be ensured through exercise. The incorrect standing, walking and sitting posture in life can be corrected through the effect of pressure and stretching in training. Long-term training can enhance the bones' ability of resistance to fracture, compression and torsion. At the same time, exercise can increase the body's slow muscles, make people's muscle structure and performance change, thus to adapt to new stimulation, establish new balance, so that students can become slender and slim.

\section{Psychological Value}

1) Inspire enthusiasm: When the physical activity achieves a certain amount of exercise, the level of arousal can be improved. Therefore, students can get rid of trouble and revivify themselves through rhythmic gymnastics training if they have annoyance and depression emotions resulted from difficulties and frustrations they encounter in the study and life.

2) Regulate anxiety: Students often generate sustained anxiety response due to many factors, and rhythmic gymnastics training can reduce the number of adrenergic receptors or sensitivity, thereby reducing students' anxiety and promote personality development.

3) Eliminate fatigue effectively: Fatigue is a comprehensive symptoms and is related to human physiological and psychological factors. When the student have negative emotion or the learning tasks exceed their individual ability, they will be physical and psychological fatigue quickly. Students' sustained and intense learning can easily lead to physical and mental fatigue and neurasthenia, and moderate training can adjust their body and mind, offering them with physical and mental relaxation, so as to eliminate fatigue.

4) Temper the will, cultivate students' quality of hardworking, tenacious and persistent: In order to carry out consistent rhythmic gymnastics training, we must always fight with our own bad characters, such as self-willed, loose, lazy, and fragile. Students need to be brave, tenacious, and persistent. Therefore, the process of getting beauty, is often the process to overcome ourselves and improve the characters.

\section{E. Aesthetic Value}

1) Cultivate students' posture beauty: As for healthy physical beauty, the only health beauty and static beauty are not enough. Dynamic beauty and the overall coordinated beauty can show people's temperament and charm much better. Rhythmic gymnastics can gradually shape the body shape through exercising basic postures of various parts of the body. The original state of students' movement can be changed through practice, to improve the flexibility of students' body and artistic expression. With the accompaniment of beautiful melody, while the body and mind are developed in an all-round way, cultivate students' wellbuilt body shape and elegant temperament, so that students can achieve the effect of muscle symmetry, proportion coordination, demeanor, graceful posture, and elegant temperament, to shape the beautiful posture.

2) Train students' correct aesthetic consciousness, and cultivate their beautiful sentiment: Through the rich content and unique training form of rhythmic gymnastics, integrate beauty into sports, enabling perfect combination of aesthetic education and physical education. Beautify human body with consciousness, to make it develop well, develop students' correct aesthetic awareness toward gesture beauty, movement beauty and figure beauty, so that students are always immersed in the enjoyment of beauty to enhance their sense of pleasure; and make students learn about charming movements, gesture, and mind. Make them pay attention to their own expression, appearance, talking, and behavior; improve their ability of correct aesthetic appreciation, establish a correct aesthetic standard and outlook on life, improve the ability of feeling, appreciation, expression and creation; strengthen personal accomplishment, to be a useful social talent with elegant temperament, excellent character and learning as well as great ideal. 


\section{CONCLUSION}

With the development of society, there are higher requirements for talents from higher vocational colleges. The demand for talents by the society is no longer the merely high vocational skills, at the same time, the talents shall have a healthy physique and good professionalism. Carrying out rhythmic gymnastics course in higher vocational colleges can effectively improve students' physical quality, strengthen body function, improve body posture, shape the well-built body shape, eliminate fatigue, improve learning efficiency, adjust the bad mood, improve literary and artistic accomplishment as well as aesthetic awareness, thus they learn how to exercise scientifically, which is helpful to cultivate comprehensive talents, playing a very important role in talent cultivation in school.

\section{REFERENCES}

[1] National Sports College Textbook Committee. Public Rhythmic Gymnastics[M].Beijing: People's Sport Publishing House, 2000.

[2] Zhu Changxi, Tan Shuping. Sports and Aesthetics [M]. Beijing: People's Sport Publishing House, 1995.

[3] Li Weidong. On the Beauty of Rhythmic Gymnastics and Aesthetics [ J] . Journal of Wuhan Institute of Physical Education, 1999, ( 2) :129.

[4] Cui Yu. Influence of Rhythmic Gymnastics Exercise on Physical Quality of Female College Students [J]. Journal of Shanghai University of Sport , 2004, 28(3): 87-91.

[5] Dong Liping. Experimental Study on Changes of Female College Students' Posture generating from Rhythmic Gymnastics [J]. Journal of Beijing Sport University, 2006, 29 (8): 1082-1083.

[6] Yang Xiaoling. Present Situation and Progress of Research on Rhythmic Gymnastics in China [J]. Journal of Tianjin University of Sport, 2002, (3).

[7] Wang Jianzhen. Expression Forms of Rhythmic Gymnastics Beauty [ J]. Journal of Wuhan Institute of Physical Education, 2003, 36 (2): 88-89. 